\title{
Reduced fertiliser use and changes in cereal grain weight, test weight and protein content in Finland in 1990-2005
}

\author{
Tapio Salo, Juha Eskelinen \\ MTT Agrifood Research Finland, Plant Production Research, FI-31600 Jokioinen, \\ Finland,e-mail: tapio.salo@mtt.fi \\ Lauri Jauhiainen \\ MTT Agrifood Research Finland, Information Management, FI-31600 Jokioinen, Finland \\ Mirja Kartio \\ Cereal Inspection, Agricultural Production Control, Finnish Food Safety Authority, Mustialankatu 3, \\ FI-00790 Helsinki, Finland
}

\begin{abstract}
Since 1995 the Finnish Agri-Environmental Program has set limits for nitrogen $(\mathrm{N})$ and phosphorus $(\mathrm{P})$ fertiliser application rates in agriculture. The decrease in $\mathrm{N}$ and $\mathrm{P}$ fertiliser recommendations, and especially the decrase in $\mathrm{N}$ and $\mathrm{P}$ amounts applied in practice, has raised the question of whether $\mathrm{N}$ and $\mathrm{P}$ application rates are too low to produce high quality yields. The test weight, 1000 grain weight and protein concentrations measured in 1990-2005 by the Cereal Inspection Unit of the Finnish Food Safety Authority were analysed against soil type, location and NP fertiliser data. The purpose of this study was to document and statistically analyse changes in fertiliser use, important quality factors and the connection between fertiliser use and grain quality of spring barley (Hordeum vulgare L.), oats (Avena sativa L.), winter rye (Secale cereale L.) as well as spring and winter wheat (Triticum aestivum L.). Applications of $\mathrm{N}$ and $\mathrm{P}$ fertiliser, test weight and 1000 grain weight have decreased in Finland since 1990-1994. Protein content began to decrease in 1995-1999, but then increased in 2000-2005. The statistical analysis showed that reduced N application rates are associated with lower test weight, 1000 grain weight and grain protein concentration. In addition, low $\mathrm{P}$ application rates were associated with reduced 1000 grain weight and protein concentration in some instances, although protein concentration also increased in winter wheat grain. The magnitude of grain quality reduction was not solely explicable through $\mathrm{N}$ and $\mathrm{P}$ application rates. During the observation period many other factors changed in Finnish cereal production and, for example, the decrease in cereal prices, increase of reduced tillage and low investments in drainage and liming could have been associated with decreased grain quality.
\end{abstract}

Key-words: nitrogen, phosphorus, fertiliser use, barley, oat, wheat, rye, quality, trend 


\section{Introduction}

Since 1995 the Finnish Agri-Environmental Program has set limits for nitrogen $(\mathrm{N})$ and phosphorus $(\mathrm{P})$ fertiliser application rates in agriculture. In addition, low grain prices have contributed to decreased use of agrochemical inputs, including fertilisers. $\mathrm{N}$ fertiliser applications to agricultural soils decreased from $110 \mathrm{~kg} \mathrm{ha}^{-1}$ at the beginning of $1990 \mathrm{~s}$ to $80 \mathrm{~kg} \mathrm{ha}^{-1}$ at the beginning of $2000 \mathrm{~s}$ (Salo et al. 2007). While $\mathrm{N}$ input as manure fell by approximately $10 \mathrm{~kg} \mathrm{ha}^{-1}$ at the same time, the total $\mathrm{N}$ input into Finnish agricultural soils is now $40 \mathrm{~kg}$ $\mathrm{ha}^{-1}$ lower than it was fifteen years ago (Salo et al. 2007). Pfertiliser application has decreased even to a greater extent. Use of $\mathrm{P}$ fertilisers decreased from $25 \mathrm{~kg} \mathrm{ha}^{-1}$ in 1990 to $8 \mathrm{~kg} \mathrm{ha}^{-1}$ in 2004. Although $\mathrm{P}$ input from manure has not changed, the total $\mathrm{P}$ applications to Finnish agricultural soils are now approximately 50\% of those in 1990 (Ministry of Agriculture and Forestry 2004, Uusitalo et al. 2007). Consequently, the 50-yr upward trend in soil-test $\mathrm{P}$ concentrations probably levelled out in the late 1990s and could slowly decrease in future (Uusitalo et al. 2007).

The decrease of $\mathrm{N}$ and $\mathrm{P}$ fertiliser recommendations (Table 1) and reduced use in practice has raised the question of whether $\mathrm{N}$ and $\mathrm{P}$ application rates are already too low to produce high quality yields. $\mathrm{N}$ fertiliser increases dry matter production and affects the protein concentration and other grain quality components. $\mathrm{P}$ supply during early crop development has a large effect on yield potential, but there might also be a requirement for an external supply of $\mathrm{P}$ during flowering and grain filling, as discussed by Grant et al. (2001). Trends in annual cereal yields on Finnish farms show negligible increases (Fig.1, Slafer and PeltonenSainio 2001), although Finnish variety trial data indicated continuous increase in the annual yields of all cereal species in 1973-2003 (Öfversten et al. 2004). This suggests that the genetic improvement of cereal varieties in trials does not translate into yield increases under actual farming conditions.

Cereal grain yield is determined by grain number per area and single grain weight. Under Finnish conditions, grain number is considered to be the more flexible and important of these two yield components (Peltonen-Sainio et al. 2007, Rajala et al. 2007). Seeding rates in Finland are high and consequently main shoot dominance does not allow much tillering (e.g. Peltonen-Sainio et al. 2007, Rajala et al. 2007). While increased application of $\mathrm{N}$ fertiliser usually increases the number of tillers and the number of grains per head, under Finnish conditions the increase in tiller number is not necessary if seed emergence is good. Additional $\mathrm{N}$ can result in more grains per head (Peltonen-Sainio and Peltonen 1995).

Since $\mathrm{N}$ application rate increases grain density (Bayles 1977), dry-matter production and leaf area duration, it might be expected that cereal grains tend to increase in weight with increasing applications

Table 1. Recommendations for $\mathrm{N}$ and $\mathrm{P}$ fertilization $\left(\mathrm{kg} \mathrm{ha}^{-1}\right)$ for cereals on clay and silt soils in southern Finland during 1990-2005. The plus sign in the case of winter cereals indicates that the first $\mathrm{N}$ application is in autumn and the second in spring. Recommendations for P are for satisfactory soil P levels (Viljavuuspalvelu 1990, 1995 and 2000).

\begin{tabular}{lccccc}
\hline Period & Oats & Spring barley & Winter rye & Spring wheat & Winter wheat \\
\hline Nitrogen, $\mathrm{kg} \mathrm{ha}^{-1}$ & & & & & \\
1990-1994 & 90 & $90^{*}$ & $50+100$ & 120 & $50+110$ \\
1995-2005 & 90 & $90^{*}$ & $20+100$ & 100 & $20+100$ \\
Phosphorus, $\mathrm{kg} \mathrm{ha}^{-1}$ & & & & & \\
1990-1994 & 20 & 20 & 20 & 20 & 20 \\
1995-2005 & 10 & 18 & 15 & 15 & 15 \\
\hline
\end{tabular}

* = recommendation for malting barley has been $80 \mathrm{~kg} \mathrm{ha}^{-1}$ 
of $\mathrm{N}$. However, by the time of anthesis, the level of $\mathrm{N}$ has already determined the number of grains per unit area and the grain weight will depend on source/sink relationships, and in particular, on the duration of grain filling (Hay and Porter 2006). Late-season drought, lodging and disease all impair photosynthesis and hence can reduce grain filling (HGCA 2006). Due to the complex associations among number of grains, $\mathrm{N}$ and other environmental factors, it is not surprising that there are experimental results where average grain weight has decreased (Pietola et al. 1999, Seppälä and Kontturi 1987), remained unaffected (Leitch and Hayes 1989, Esala 1991, Oscarsson et al. 1998, Browne et al. 2006) or increased (Chalmers et al. 1998, May et al. 2004, Mohr et al. 2007) following reduced $\mathrm{N}$ fertiliser application rate.

Test weight reflects packing properties of individual grains, and is influenced by grain size, moisture, ill-defined aspects of grain shape, texture of the grain surface, pre-harvest weathering and content of non-grain material (Bayles 1977). Nitrogen increases grain protein concentration, which increases grain density and can thus improve test and 1000 grain weight (Bayles 1977). The decrease in test weight at the higher rates of $\mathrm{N}$ application can be caused by incomplete grain filling, associated with higher shoot numbers and resulting in increased screenings passing $2 \mathrm{~mm}$ sieve $(\mathrm{Ohm}$ 1976, Marshall et al. 1987). In Canadian studies with oat (Avena sativa L.), high $\mathrm{N}$ fertiliser application rates increased yield and panicles per square metre but decreased 1000 grain and test weight (May et al. 2004, Mohr et al. 2007). The changes in test weights of spring barley (Hordeum vulgare L.) (Taylor and Blackett 1982, Oscarsson et al. 1998) and oats (Browne et al. 2003) due to different $\mathrm{N}$ application rates have been small compared with differences among varieties.

Phosphorus deficiency delays phasic development and depresses the number of fertile tillers (Elliot et al. 1997). Under Finnish conditions of a short growing season, delayed plant development considerably increases risks of poor grain quality. Saarela et al. (1995) reported that without $\mathrm{P}$ fertiliser, 1000 grain and test weight were particularly decreased for barley. Phosphorus deficiency also reduced grain weight (Elliot et al. 1997, Hoppo et al. 1999) as inadequate $P$ supply during grain filling can depress photosynthesis (Grant et al. 2001).

In our study, the cereal quality database maintained by the Cereal Inspection Unit of the Finnish Food Safety Authority, formerly the Grain Laboratory of the Plant Production Inspection Centre, was analysed considering soil type, location and NP fertiliser data. Five cereal crops were selected for this study: spring barley, oats, winter rye (Secale cereale L.), as well as spring and winter wheat (Triticum aestivum L.). As crop variety effect was considered in the statistical analysis, two- and sixrow barley were analysed together. Spring barley occupies approximately $25 \%$, oats $20 \%$, spring and winter wheat less than $10 \%$ and winter rye $1-2 \%$ of Finland's agricultural land area. Wheat is usually milled for bread making, but depending on annual growing conditions $10-40 \%$ of the yield is consumed as animal feed (Information Centre of Ministry of Agriculture 1991-2005). Considering the quality factors under study, test weight and protein concentration are the main criteria used by millers in defining milling quality and for determining grain price. Grain quality for seed production is defined by 1000 grain weight. The purpose of this study was to investigate the changes in fertiliser use, important grain quality factors and interactions among them.

\section{Material and methods}

\section{Data}

The Cereal Inspection Unit of the Finnish Food Safety Authority has monitored cereal yield quality since 1966. Farmers collect and send grain samples to the unit together with background data. The farms participating in the study were chosen on a regional basis by sampling from the data service register of the Ministry of Agriculture and Forestry. The sampling protocol for all cereals included test weight, 1000 grain weight and protein concentration. The background data included $\mathrm{N}$ and $\mathrm{P}$ fertiliser application rates, crop variety, soil type and 
agricultural districts (rural centres). In the animal manures, soluble $\mathrm{N}$ and total $\mathrm{P}$ were considered (Viljavuuspalvelu 1990, 1995 and 2000). The numbers of varieties of spring barley, oats, spring wheat, winter rye and winter wheat were 53, 25, 21, 16 and 13 , respectively. The number of analysed cereal samples varied annually between 1100 and 2200 . The results from annual quality analyses and trends over years are published annually by the Finnish Food Safety Authority, but the connection between $\mathrm{N}$ and $\mathrm{P}$ fertiliser application rates and quality data has not been analysed previously.

There are some problems with the reliability of the data. Grain samples sent from a farm are not necessarily strictly connected with the background data. The connection between grain sample and background data depends on how precisely a farmer can organise drying and storage of a given cereal lot from a given field. Background data can also originate from a field with different soil types and fertiliser application rates, the background data given by the farmer representing an average of prevailing conditions. Concerning the connection between $\mathrm{P}$ fertiliser application rates and cereal quality, the main problem is the lack of soil $\mathrm{P}$ values in the background data. As $\mathrm{P}$ fertiliser application rates should depend on soil

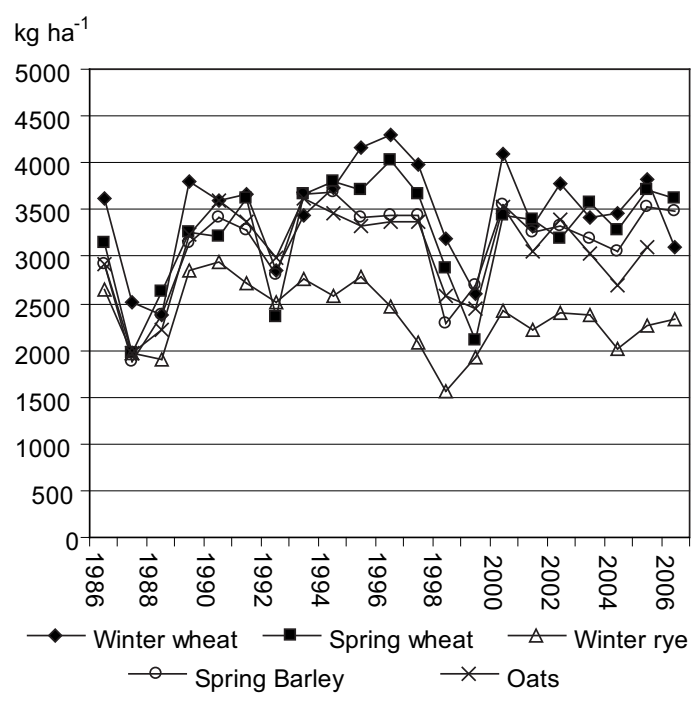

Fig. 1. Cereal yields in Finland in 1986-2006 (Information Centre of the Ministry of Agriculture 1987-2005).
$\mathrm{P}$ values, statistical tests between values for $\mathrm{P}$ fertiliser rates and cereal quality can be supposed to be very approximate.

The total numbers of samples for spring barley, oats, spring wheat, winter rye and winter wheat were 8901, 8802, 4493, 1613 and 1467, respectively. While $68 \%$ of samples were collected from clay soils, sandy and organic soils were represented by $17 \%$ and $16 \%$ of samples, respectively. Cultivation area of oats and spring barley included the whole country, i.e. samples were collected from all 20 rural centres distributed nationwide (Salo et al. 2007, Fig. 1). Samples of spring wheat and winter rye were collected mainly from 18 and those of winter wheat from 8 centres, respectively.

\section{Statistical analysis}

The data were divided into three classes, where 1990-1994 represented the time before the AgriEnvironmental Program, while 1995-1999 and 2000-2005 represented two periods during the Agri-Environmental Program. At the beginning of the statistical analysis, $\mathrm{N}$ and $\mathrm{P}$ fertiliser application rates for spring barley, oats, winter rye, and spring and winter wheat were compared over the three time periods using mixed models with a REMLestimation method. Variety and rural centre were set as random effects and year was a fixed effect in the models. As fertiliser recommendations are made according to the soil types, soil type and soil typeby-year interaction were included in the statistical analysis. Because cultivation area of winter wheat is small and $94 \%$ of samples were collected from clay soils, it was not possible to take soil type into account in statistical analysis of winter wheat. The distribution of $\mathrm{P}$ fertiliser application rates was skewed and logarithmic transformation was done to normalise the data. All results were subsequently transformed back to the original scale.

As fertiliser application rates were statistically significantly lower on all soil types in the later time periods than in 1990-1994, the difference between time periods was analysed in terms of test weight, 1000 grain weight and grain protein concentration. 
Cereal grain quality varied widely from year to year and among rural centres within years as a result of different weather conditions. Conditions in one rural centre and year combination were quite similar, and therefore the effects of different fertiliser application rates were also examined within centre-year combinations. These analyses were done using a random coefficient regression model (Littell et al. 1996, p. 253-266) in which effects of fertilisers were assumed to be linear. Fertiliser effects were estimated for each rural centre-year combination and variety was treated as a covariate. Soil type was an additional covariate when analysing $\mathrm{N}$ fertiliser effect, but soil type did not influence results of the P fertiliser effect and was excluded from that analysis. Effects of $\mathrm{N}$ and $\mathrm{P}$ were estimated for two time periods, 1990-1994 and 1995-2005. Fertiliser effect was then compared between these two time periods.

All statistical analyses were performed using SAS/MIXED-software (Littell et al. 1996). Scatter plots of residuals and fitted values revealed some outliers, but because of their small size they did not influence the results. Graphical description of data revealed some clearly incorrect records and those were removed from the data before statistical analysis.

Table 2. The average $\mathrm{N}$ fertiliser application rate $\left(\mathrm{kg} \mathrm{ha}^{-1}\right)$ for different soil types in 1990-1994, 1995-1999 and 2000-2005 and statistical significance $(p)$ of time periods compared to the first time period (1990-1994).

\begin{tabular}{|c|c|c|c|c|c|c|}
\hline \multirow[b]{2}{*}{ Crop } & \multirow{2}{*}{\multicolumn{2}{|c|}{ Period }} & \multicolumn{3}{|c|}{ Soil type } & \multirow[b]{2}{*}{ S.E. } \\
\hline & & & Clay & Sand & Organic & \\
\hline \multirow[t]{5}{*}{ Oats } & A & 1990-1994 & 94.0 & 93.9 & 77.2 & 1.62 \\
\hline & B & 1995-1999 & 86.6 & 88.4 & 76.3 & 1.61 \\
\hline & $\mathrm{C}$ & 2000-2005 & 84.2 & 82.6 & 74.9 & 1.64 \\
\hline & & $p:$ A vs. B & $<0.001$ & 0.01 & 0.58 & \\
\hline & & $p: \mathrm{A}$ vs. C & $<0.001$ & $<0.001$ & 0.12 & \\
\hline \multirow[t]{5}{*}{ Spring barley } & A & 1990-1994 & 97.8 & 90.0 & 80.3 & 1.67 \\
\hline & B & 1995-1999 & 87.0 & 90.3 & 75.9 & 1.64 \\
\hline & $\mathrm{C}$ & 2000-2005 & 85.7 & 83.1 & 76.3 & 1.59 \\
\hline & & $p:$ A vs. B & $<0.001$ & 0.91 & 0.04 & \\
\hline & & $p: \mathrm{A}$ vs. C & $<0.001$ & $<0.001$ & 0.05 & \\
\hline \multirow{5}{*}{ Winter rye } & A & 1990-1994 & 115.1 & 91.5 & 107.6 & 5.22 \\
\hline & B & 1995-1999 & 88.6 & 75.4 & 67.8 & 5.21 \\
\hline & $\mathrm{C}$ & 2000-2005 & 72.1 & 74.6 & 56.8 & 5.10 \\
\hline & & $p: \mathrm{A}$ vs. B & $<0.001$ & 0.05 & $<0.001$ & \\
\hline & & $p: \mathrm{A}$ vs. C & $<0.001$ & 0.02 & $<0.001$ & \\
\hline \multirow[t]{5}{*}{ Spring wheat } & $\mathrm{A}$ & 1990-1994 & 117.7 & 110.7 & 102.4 & 3.06 \\
\hline & B & 1995-1999 & 104.4 & 97.0 & 95.0 & 3.11 \\
\hline & $\mathrm{C}$ & 2000-2005 & 98.6 & 97.3 & 88.6 & 3.03 \\
\hline & & $p: \mathrm{A}$ vs. B & $<0.001$ & 0.01 & 0.10 & \\
\hline & & $p: \mathrm{A}$ vs. C & $<0.001$ & $<0.001$ & $<0.001$ & \\
\hline \multirow[t]{5}{*}{ Winter wheat } & $\mathrm{A}$ & 1990-1994 & 153.0 & & & 6.04 \\
\hline & B & 1995-1999 & 129.7 & & & 5.88 \\
\hline & $\mathrm{C}$ & $2000-2005$ & 116.5 & & & 6.15 \\
\hline & & $p: \mathrm{A}$ vs. B & $<0.001$ & & & \\
\hline & & $p:$ A vs. C & $<0.001$ & & & \\
\hline
\end{tabular}

S.E. $=$ standard error of the mean for clay soil 


\section{Results}

\section{Fertiliser application rates}

Application rates of $\mathrm{N}$ clearly decreased after 1990-1994 (Table 2). The decrease was statistically significant for all cereals on clay and sandy soils, excluding spring barley, and winter rye until 2000 on sandy soils. On organic soils the observed decrease in $\mathrm{N}$ application rates was slight, but for the studied cereals the number of samples from organic soils was rather low $(\mathrm{n}=144-2149)$. The decrease in $\mathrm{N}$ application rates on mineral soils was $10 \mathrm{~kg} \mathrm{ha}^{-1}\left(\right.$ S.E. $\left.=1.1-1.9 \mathrm{~kg} \mathrm{ha}^{-1}\right)$ for spring barley and oats, $30 \mathrm{~kg} \mathrm{ha}^{-1}$ (S.E. $=3.2 \mathrm{~kg} \mathrm{ha}^{-1}$ ) for winter rye, $17 \mathrm{~kg} \mathrm{ha}^{-1}\left(\right.$ S.E. $\left.=1.6 \mathrm{~kg} \mathrm{ha}^{-1}\right)$ for spring wheat and $36 \mathrm{~kg} \mathrm{ha}^{-1}\left(\right.$ S.E. $\left.=3.4 \mathrm{~kg} \mathrm{ha}^{-1}\right)$ for winter wheat during the observation period.

Application rates of $\mathrm{P}$ have decreased by 25-40\% since 1990-1994 (Table 3). The decrease has been statistically significant for all cereals on all soils with the exception of winter rye from 1990-1994 to 1995-1999 on sandy soils. The decrease in $\mathrm{P}$ application rates was $7 \mathrm{~kg} \mathrm{ha}^{-1}$ for spring barley and spring wheat, $9 \mathrm{~kg} \mathrm{ha}^{-1}$ for oats, $10 \mathrm{~kg} \mathrm{ha}^{-1}$ for winter rye and $12 \mathrm{~kg} \mathrm{ha}^{-1}$ for winter wheat during the observation period.

Table 3. The average $\mathrm{P}$ fertiliser application rate $\left(\mathrm{kg} \mathrm{ha}^{-1}\right)$ on different soil types in 1990-1994, 1995-1999 and 2000-2005 and statistical significance $(p)$ of time periods compared with the first time period (1990-1994).

\begin{tabular}{|c|c|c|c|c|c|}
\hline \multirow[b]{2}{*}{ Crops } & & \multirow[b]{2}{*}{ Period } & \multicolumn{3}{|c|}{ Soil type } \\
\hline & & & Clay & Sand & Organic \\
\hline \multirow[t]{5}{*}{ Oats } & $\mathrm{A}$ & 1990-1994 & 21.7 & 23.6 & 22.3 \\
\hline & $\mathrm{B}$ & 1995-1999 & 15.7 & 16.6 & 15.2 \\
\hline & $\mathrm{C}$ & 2000-2005 & 14.1 & 14.0 & 13.5 \\
\hline & & p: A vs. B & $<0.001$ & $<0.001$ & $<0.001$ \\
\hline & & p: A vs. C & $<0.001$ & $<0.001$ & $<0.001$ \\
\hline \multirow[t]{5}{*}{ Spring barley } & A & 1990-1994 & 21.9 & 23.6 & 22.2 \\
\hline & B & 1995-1999 & 16.0 & 18.1 & 16.8 \\
\hline & $\mathrm{C}$ & $2000-2005$ & 15.7 & 16.4 & 15.0 \\
\hline & & $p: \mathrm{A}$ vs. B & $<0.001$ & $<0.001$ & $<0.001$ \\
\hline & & $p: \mathrm{A}$ vs. $\mathrm{C}$ & $<0.001$ & $<0.001$ & $<0.001$ \\
\hline \multirow[t]{5}{*}{ Winter rye } & A & 1990-1994 & 25.9 & 20.1 & 28.0 \\
\hline & B & 1995-1999 & 15.8 & 18.1 & 13.6 \\
\hline & $\mathrm{C}$ & 2000-2005 & 12.7 & 13.1 & 14.1 \\
\hline & & $p: \mathrm{A}$ vs. B & $<0.001$ & 0.50 & $<0.001$ \\
\hline & & $p:$ A vs. C & $<0.001$ & $<0.01$ & $<0.001$ \\
\hline \multirow[t]{5}{*}{ Spring wheat } & A & 1990-1994 & 22.5 & 21.4 & 21.4 \\
\hline & B & 1995-1999 & 16.1 & 15.8 & 17.0 \\
\hline & $\mathrm{C}$ & 2000-2005 & 15.0 & 16.4 & 13.8 \\
\hline & & $p: \mathrm{A}$ vs. B & $<0.001$ & $<0.01$ & $<0.01$ \\
\hline & & $p:$ A vs. C & $<0.001$ & $<0.001$ & $<0.001$ \\
\hline \multirow[t]{5}{*}{ Winter wheat } & A & 1990-1994 & 23.7 & & \\
\hline & B & 1995-1999 & 13.6 & & \\
\hline & $\mathrm{C}$ & 2000-2005 & 11.8 & & \\
\hline & & $p: \mathrm{A}$ vs. B & $<0.001$ & & \\
\hline & & $p:$ A vs. C & $<0.001$ & & \\
\hline
\end{tabular}


Vol. 16 (2007): 407-420

\section{Cereal quality}

Cereal and soil type combinations had 2-4\% coefficients of variation for annual test weight means over 16 years. In addition to annual variation, there seemed to be a decreasing trend since 1994 (Table 4). The decrease was statistically significant for all cereals on all soils, excluding winter rye until 2000 on sandy soil, spring wheat after 2000 on sandy soil and until 2000 on organic soil (Table 4). The averaged decrease in test weight over soil types was $1.7 \mathrm{~kg}$ (S.E. $=0.12 \mathrm{~kg}$ ) for oats, $3.7 \mathrm{~kg}$ (S.E. = $0.21 \mathrm{~kg}$ ) for spring barley, $1.2 \mathrm{~kg}$ (S.E. $=0.23 \mathrm{~kg}$ ) for spring wheat, $2.1 \mathrm{~kg}$ (S.E. $=0.29 \mathrm{~kg}$ ) for winter rye and $1.5 \mathrm{~kg}$ (S.E. $=0.23 \mathrm{~kg}$ ) for winter wheat during the observation period.

Coefficients of variation for annual 1000 grain weights over 16 years were 4-8\% among different cereal and soil type combinations. In addition to annual variation, there seemed to be a similar decreasing trend since 1990 as for test weights (Table 5). The decrease was statistically significant

Table 4. The average test weight (kg) for different cereals in 1990-1994, 1995-1999 and 2000-2005 and statistical significance $(p)$ of time periods compared with the first time period (1990-1994).

\begin{tabular}{|c|c|c|c|c|c|c|}
\hline \multirow[b]{2}{*}{ Crop } & \multirow{2}{*}{\multicolumn{2}{|c|}{ Period }} & \multicolumn{3}{|c|}{ Soil type } & \multirow[b]{2}{*}{ S.E. } \\
\hline & & & Clay & Sand & Organic & \\
\hline \multirow[t]{5}{*}{ Oats } & A & 1990-1994 & 56.6 & 56.5 & 55.8 & 0.32 \\
\hline & B & 1995-1999 & 56.3 & 55.8 & 55.2 & 0.32 \\
\hline & $\mathrm{C}$ & $2000-2005$ & 54.7 & 54.5 & 54.5 & 0.31 \\
\hline & & $p:$ A vs. B & 0.02 & 0.01 & $<0.01$ & \\
\hline & & $p:$ A vs. C & $<0.001$ & $<0.001$ & $<0.001$ & \\
\hline \multirow[t]{5}{*}{ Spring barley } & A & 1990-1994 & 66.9 & 66.8 & 65.6 & 0.53 \\
\hline & B & 1995-1999 & 65.1 & 64.8 & 64.2 & 0.52 \\
\hline & $\mathrm{C}$ & 2000-2005 & 63.0 & 62.9 & 62.2 & 0.52 \\
\hline & & $p:$ A vs. B & $<0.001$ & $<0.001$ & $<0.001$ & \\
\hline & & $p:$ A vs. C & $<0.001$ & $<0.001$ & $<0.001$ & \\
\hline \multirow[t]{5}{*}{ Winter rye } & A & 1990-1994 & 75.1 & 75.2 & 75.0 & 0.57 \\
\hline & B & 1995-1999 & 73.7 & 74.1 & 73.8 & 0.57 \\
\hline & $\mathrm{C}$ & 2000-2005 & 73.3 & 73.3 & 72.3 & 0.56 \\
\hline & & $p: \mathrm{A}$ vs. B & $<0.001$ & 0.05 & 0.09 & \\
\hline & & $p:$ A vs. C & $<0.001$ & $<0.001$ & $<0.001$ & \\
\hline \multirow[t]{5}{*}{ Spring wheat } & A & 1990-1994 & 80.5 & 79.7 & 79.2 & 0.45 \\
\hline & B & 1995-1999 & 78.8 & 78.3 & 79.0 & 0.45 \\
\hline & $\mathrm{C}$ & $2000-2005$ & 78.6 & 79.3 & 77.9 & 0.45 \\
\hline & & $p:$ A vs. B & $<0.001$ & 0.01 & 0.67 & \\
\hline & & $p:$ A vs. C & $<0.001$ & 0.44 & $<0.001$ & \\
\hline \multirow[t]{5}{*}{ Winter wheat } & A & 1990-1994 & 81.1 & & & 0.31 \\
\hline & B & 1995-1999 & 79.5 & & & 0.32 \\
\hline & $\mathrm{C}$ & 2000-2005 & 79.6 & & & 0.32 \\
\hline & & $p:$ A vs. B & $<0.001$ & & & \\
\hline & & $p:$ A vs. C & $<0.001$ & & & \\
\hline
\end{tabular}

S.E. $=$ standard error of the mean for clay soil 


\section{AGRICULTURAL AND FOOD SCIENCE}

Salo, T. et al. Cereal quality changes in Finland in 1990-2005

for all cereals on all soils, excluding winter rye until 2000 on sandy soil (Table 5). The averaged decrease for 1000 grain weight over all soil types was $1.1 \mathrm{~g}$ (S.E. $=0.11 \mathrm{~g})$ for oats, $4.0 \mathrm{~g}$ (S.E. = $0.23 \mathrm{~g}$ ) for spring barley, $3.1 \mathrm{~g}($ S.E. $=0.25 \mathrm{~g})$ for spring wheat, $2.5 \mathrm{~g}$ (S.E. $=0.32 \mathrm{~g}$ ) for winter rye and $2.9 \mathrm{~g}$ (S.E. $=0.33 \mathrm{~g}$ ) for winter wheat during the observation period.

Cereal and soil type combinations had $5-7 \%$ coefficients of variation for annual protein concen- trations over 16 years. In addition to annual variation, first there was a decreasing trend that changed to an increasing one after 1999 (Table 6). For oats, spring barley and winter wheat, protein concentrations were statistically significantly lower in 1995-1999 and higher in 2000-2005 compared with 1990-1994. Protein concentrations for winter rye and spring wheat did not clearly change from one observation period to the other.

Table 5. The average 1000 grain weight (g) for different cereals in 1990-1994, 1995-1999 and 2000-2005 and statistical significance $(p)$ of time periods compared with the first time period (1990-1994).

\begin{tabular}{|c|c|c|c|c|c|c|}
\hline \multirow[b]{2}{*}{ Crop } & \multirow{2}{*}{\multicolumn{2}{|c|}{ Period }} & \multicolumn{3}{|c|}{ Soil type } & \multirow[b]{2}{*}{ S.E. } \\
\hline & & & Clay & Sand & Organic & \\
\hline \multirow[t]{5}{*}{ Oats } & A & 1990-1994 & 32.6 & 32.6 & 31.9 & 0.45 \\
\hline & B & 1995-1999 & 31.6 & 31.4 & 31.0 & 0.45 \\
\hline & $\mathrm{C}$ & 2000-2005 & 31.4 & 31.3 & 31.2 & 0.45 \\
\hline & & $p:$ A vs. B & $<0.001$ & $<0.001$ & $<0.001$ & \\
\hline & & $p:$ A vs. C & $<0.001$ & $<0.001$ & $<0.001$ & \\
\hline \multirow[t]{5}{*}{ Spring barley } & A & 1990-1994 & 40.3 & 39.8 & 39.3 & 0.78 \\
\hline & B & 1995-1999 & 37.4 & 37.1 & 36.8 & 0.77 \\
\hline & $\mathrm{C}$ & $2000-2005$ & 36.4 & 35.7 & 35.3 & 0.77 \\
\hline & & $p:$ A vs. B & $<0.001$ & $<0.001$ & $<0.001$ & \\
\hline & & $p: \mathrm{A}$ vs. C & $<0.001$ & $<0.001$ & $<0.001$ & \\
\hline \multirow[t]{5}{*}{ Winter rye } & A & 1990-1994 & 26.9 & 26.9 & 26.2 & 0.66 \\
\hline & B & 1995-1999 & 25.1 & 25.7 & 24.5 & 0.65 \\
\hline & $\mathrm{C}$ & 2000-2005 & 24.5 & 24.6 & 23.5 & 0.64 \\
\hline & & $p:$ A vs. B & $<0.001$ & 0.06 & 0.02 & \\
\hline & & $p:$ A vs. C & $<0.001$ & $<0.001$ & $<0.001$ & \\
\hline \multirow[t]{5}{*}{ Spring wheat } & A & 1990-1994 & 36.4 & 35.9 & 36.2 & 0.51 \\
\hline & B & 1995-1999 & 33.9 & 34.2 & 34.4 & 0.51 \\
\hline & $\mathrm{C}$ & $2000-2005$ & 33.4 & 33.5 & 32.3 & 0.50 \\
\hline & & $p:$ A vs. B & $<0.001$ & $<0.01$ & $<0.001$ & \\
\hline & & $p:$ A vs. C & $<0.001$ & $<0.001$ & $<0.001$ & \\
\hline \multirow[t]{5}{*}{ Winter wheat } & A & 1990-1994 & 39.6 & & & 0.73 \\
\hline & $\mathrm{B}$ & 1995-1999 & 37.1 & & & 0.74 \\
\hline & $\mathrm{C}$ & 2000-2005 & 36.7 & & & 0.74 \\
\hline & & $p:$ A vs. B & $<0.001$ & & & \\
\hline & & $p:$ A vs. C & $<0.001$ & & & \\
\hline
\end{tabular}

S.E. = standard error of the mean for clay soil 
Vol. 16 (2007): 407-420

Table 6. The average protein concentration (\%) for different cereals in 1990-1994, 1995-1999 and 2000-2005 and statistical significance $(p)$ of time periods compared with the first time period (1990-1994).

\begin{tabular}{|c|c|c|c|c|c|c|}
\hline \multirow[b]{2}{*}{ Crop } & \multirow{2}{*}{\multicolumn{2}{|c|}{ Period }} & \multicolumn{3}{|c|}{ Soil type } & \multirow[b]{2}{*}{ S.E. } \\
\hline & & & Clay & Sand & Organic & \\
\hline \multirow[t]{5}{*}{ Oats } & A & 1990-1994 & 13.4 & 12.9 & 13.3 & 0.24 \\
\hline & B & 1995-1999 & 13.0 & 12.9 & 13.2 & 0.24 \\
\hline & $\mathrm{C}$ & 2000-2005 & 13.2 & 13.2 & 13.6 & 0.24 \\
\hline & & $p:$ A vs. B & $<0.001$ & 0.88 & 0.02 & \\
\hline & & $p:$ A vs. C & $<0.01$ & $<0.01$ & $<0.001$ & \\
\hline \multirow[t]{5}{*}{ Spring barley } & A & 1990-1994 & 12.2 & 11.6 & 12.3 & 0.14 \\
\hline & B & 1995-1999 & 11.7 & 11.7 & 12.0 & 0.14 \\
\hline & $\mathrm{C}$ & $2000-2005$ & 12.7 & 12.8 & 13.2 & 0.13 \\
\hline & & $p:$ A vs. B & $<0.001$ & 0.20 & $<0.01$ & \\
\hline & & $p:$ A vs. C & $<0.001$ & $<0.001$ & $<0.001$ & \\
\hline \multirow[t]{5}{*}{ Winter rye } & A & 1990-1994 & 11.3 & 11.1 & 11.4 & 0.20 \\
\hline & B & 1995-1999 & 11.2 & 10.9 & 11.5 & 0.20 \\
\hline & $\mathrm{C}$ & $2000-2005$ & 11.2 & 11.3 & 11.5 & 0.19 \\
\hline & & $p:$ A vs. B & 0.70 & 0.35 & 0.91 & \\
\hline & & $p:$ A vs. C & 0.75 & 0.26 & 0.75 & \\
\hline \multirow[t]{5}{*}{ Spring wheat } & A & 1990-1994 & 13.8 & 13.6 & 13.6 & 0.18 \\
\hline & B & 1995-1999 & 13.0 & 13.2 & 13.3 & 0.18 \\
\hline & $\mathrm{C}$ & $2000-2005$ & 13.9 & 13.7 & 14.0 & 0.18 \\
\hline & & $p:$ A vs. B & $<0.001$ & 0.09 & 0.16 & \\
\hline & & $p:$ A vs. C & 0.44 & 0.67 & 0.08 & \\
\hline \multirow[t]{5}{*}{ Winter wheat } & A & 1990-1994 & 12.2 & & & 0.13 \\
\hline & B & 1995-1999 & 11.8 & & & 0.14 \\
\hline & $\mathrm{C}$ & 2000-2005 & 12.6 & & & 0.14 \\
\hline & & $p:$ A vs. B & $<0.001$ & & & \\
\hline & & $p:$ A vs. C & $<0.001$ & & & \\
\hline
\end{tabular}

S.E. $=$ standard error of the mean for clay soil

\section{Fertiliser effect on cereal quality}

Comparisons of different fertiliser application rates within rural centre-year combinations showed that the effect of $\mathrm{N}$ fertiliser was statistically significant on test weights of spring barley, oats and spring wheat (Table 7). The effect was highest on spring barley, $0.015-0.018 \mathrm{~kg}$ per $1 \mathrm{~kg}$ fertiliser $\mathrm{N}$. There were no statistical differences for $\mathrm{N}$ fertiliser effects between 1990-1994 and 1995-2005. Phosphorus application rate had no statistically significant effect on test weights (Table 8).

$\mathrm{N}$ application rate increased grain weight of spring barley and spring wheat, but decreased that of winter rye in 1995-2005 (Table 7). The increase was highest for spring barley, 0.009-0.010 g per $1 \mathrm{~kg}$ fertiliser $\mathrm{N}$. The effect of $\mathrm{P}$ fertiliser was statistically significant for 1000 grain weight of spring barley and spring wheat (Table 8). The increase was 0.023 and $0.007 \mathrm{~g}$ per $1 \mathrm{~kg}$ fertiliser 
P for spring barley and spring wheat, respectively. For spring wheat there was a difference between time periods, suggesting that $\mathrm{P}$ fertilisation had a more positive effect on 1000 grain weight after 1995.

Fertiliser $\mathrm{N}$ had a positive effect on grain protein concentration for all cereals excluding winter rye (Table 7). The effect varied from $0.003-0.007 \%$ unit per $1 \mathrm{~kg}$ fertiliser N. For oats, there was also a difference between time periods, suggesting that $\mathrm{N}$ fertilisation had a less positive effect on protein concentration after 1995. Rate of $\mathrm{P}$ application had a positive effect on protein concentration of spring barley and oats, but a negative effect on winter wheat (Table 8). These positive effects were $0.003-0.004 \%$ unit per $1 \mathrm{~kg}$ fertiliser $\mathrm{P}$ and the negative effect was $-0.013 \%$ unit per $1 \mathrm{~kg}$ fertiliser P. For winter wheat, there was also a difference between time periods, suggesting that $\mathrm{P}$ fertiliser had a negative effect on protein concentration only after 1995 .

\section{Discussion}

\section{Fertiliser application rates}

Data for Finnish cereal inspection show that use of fertiliser $\mathrm{N}$ and $\mathrm{P}$ has clearly decreased since 1990. This reduction was reported also in other studies (Ministry of Agriculture and Forestry 2004, Salo et al. 2007, Uusitalo et al. 2007). Fertiliser use decreased mostly in 1995-1999 and the further decrease in 2000-2005 was more modest. In the analysis of this dataset, the $\mathrm{N}$ and $\mathrm{P}$ fertilisers applied as mineral fertilisers and as manure should also be considered separately. In the present study soluble $\mathrm{N}$ and total $\mathrm{P}$ contents of manure were used, according to average values, and were considered equivalent to the nutrients from mineral fertilisers. In reality, manure nutrients, compared with mineral fertilisers, are not so readily available and furthermore, their utilisation depends on the time of application (Turtola and Kemppainen 1998).

\section{Test weight and 1000 grain weight}

There is clear evidence that test weight and 1000 grain weight decreased in Finland since 1990-1994. While investigating reasons for decreased grain quality, other changes must be considered in addition to decreased fertiliser application rates in Finnish cereal production. The decrease in grain price by more than $50 \%$ during the studied period almost certainly decreased inputs in cereal production. The use of fungicides was lower in 1995-1999 than in 1990-1994, although it returned to a similar level in 2000-2005 (Ministry of Agriculture and Forestry 2004, Information Centre of the Ministry of Agriculture 2005). Fungicide application prolongs leaf area duration in years with high disease risk. Fungicide applications increased test weight by $0.5-4.0 \mathrm{~kg}$, depending on disease risk (Salopelto 2004, 2005). The area of reduced tillage also increased during the study period (Ministry of Agriculture and Forestry 2004), but the collected data suggest that reduced tillage mainly affected the crop yields and not crop quality (Salopelto 2005).

Our results show a slight increase in test weight due to increased $\mathrm{N}$ fertilisation. However, the effect of one kilogram of fertiliser $\mathrm{N}$ is rather small and not biologically significant. For example, the observed $20 \mathrm{~kg} \mathrm{ha}^{-1}$ reduction in $\mathrm{N}$ application rate for spring wheat resulted in only a $0.2 \mathrm{~kg}$ decrease in test weight. The average decrease in spring wheat test weight during the studied periods was $1.9 \mathrm{~kg}$. Thus, the reduced $\mathrm{N}$ application rate explained only about $10 \%$ of the test weight decrease. However, it is interesting that this association between increased $\mathrm{N}$ application rates and test weight contrasts with results of most field experiments. In the cited field experiment studies where test weight decreased due to the increased $\mathrm{N}$ application, $\mathrm{N}$ application rates were 15 and $80 \mathrm{~kg} \mathrm{ha}^{-1}$ (May et al. 2004), 0, 40, 80 and $120 \mathrm{~kg} \mathrm{ha}^{-1}$ (Mohr et al. 2007) or 45, 90 and $135 \mathrm{~kg} \mathrm{ha}^{-1}$ (Oscarsson et al. 1998). Rates of $\mathrm{N}$ application in our study had standard deviations of 23-44 $\mathrm{kg} \mathrm{ha}^{-1}$ (Table 7), but in the year by rural centre combinations, $\mathrm{N}$ application rates most probably differed much less than 
Vol. 16 (2007): 407-420

Table 7. Effect of $1 \mathrm{~kg} \mathrm{~N}$ fertiliser on grain quality.

\begin{tabular}{|c|c|c|c|c|c|c|c|c|c|c|}
\hline \multirow{2}{*}{$\begin{array}{l}\text { Cereal } \\
\text { Period }\end{array}$} & \multirow{2}{*}{$\begin{array}{l}\mathrm{N} \text { rate } \\
\text { mean } \pm \mathrm{SD} \\
\mathrm{kg} \mathrm{ha}^{-1}\end{array}$} & \multicolumn{3}{|c|}{ Test weight } & \multicolumn{3}{|c|}{1000 grain weight } & \multicolumn{3}{|c|}{ Protein concentration } \\
\hline & & $\begin{array}{l}\text { Effect } \\
\mathrm{kg} \mathrm{kg}^{-1}\end{array}$ & $\begin{array}{l}\text { S.E. } \\
\mathrm{kg} \mathrm{kg}^{-1}\end{array}$ & $p$ & $\begin{array}{l}\text { Effect } \\
\text { g kg-1 }\end{array}$ & $\begin{array}{l}\text { S.E. } \\
\mathrm{g} \mathrm{kg}^{-1}\end{array}$ & $p$ & $\begin{array}{l}\text { Effect } \\
\% \mathrm{~kg}^{-1}\end{array}$ & $\begin{array}{l}\text { S.E. } \\
\% \mathrm{~kg}^{-1}\end{array}$ & $p$ \\
\hline \multicolumn{11}{|l|}{ Spring barley } \\
\hline 1990-1994 & $94 \pm 30$ & 0.015 & 0.0042 & $<0.001$ & 0.009 & 0.0038 & 0.02 & 0.006 & 0.0011 & $<0.001$ \\
\hline 1995-2005 & $85 \pm 26$ & 0.018 & 0.0028 & $<0.001$ & 0.010 & 0.0026 & $<0.001$ & 0.004 & 0.0008 & $<0.001$ \\
\hline change & & 0.003 & 0.0050 & 0.55 & 0.002 & 0.0046 & 0.73 & -0.002 & 0.0014 & 0.15 \\
\hline \multicolumn{11}{|l|}{ Oats } \\
\hline 1990-1994 & $89 \pm 23$ & 0.004 & 0.0027 & 0.12 & 0.000 & 0.0023 & 0.85 & 0.005 & 0.0010 & $<0.001$ \\
\hline 1995-2005 & $83 \pm 25$ & 0.007 & 0.0018 & $<0.001$ & -0.002 & 0.0015 & 0.18 & 0.003 & 0.0006 & $<0.001$ \\
\hline change & & 0.003 & 0.0031 & 0.40 & -0.002 & 0.0027 & 0.56 & -0.002 & 0.0011 & 0.05 \\
\hline \multicolumn{11}{|l|}{ Spring wheat } \\
\hline 1990-1994 & $118 \pm 29$ & 0.012 & 0.0037 & $<0.01$ & 0.006 & 0.0031 & 0.04 & 0.007 & 0.0013 & $<0.001$ \\
\hline 1995-2005 & $108 \pm 26$ & 0.009 & 0.0028 & $<0.01$ & 0.006 & 0.0025 & 0.02 & 0.006 & 0.0011 & $<0.001$ \\
\hline change & & -0.003 & 0.0046 & 0.50 & 0.000 & 0.0040 & 0.91 & -0.001 & 0.0017 & 0.59 \\
\hline \multicolumn{11}{|l|}{ Winter wheat } \\
\hline 1990-1994 & $154 \pm 44$ & 0.005 & 0.0033 & 0.14 & 0.002 & 0.0035 & 0.50 & 0.007 & 0.0012 & $<0.001$ \\
\hline $1995-1005$ & $132 \pm 38$ & 0.002 & 0.0030 & 0.43 & -0.004 & 0.0034 & 0.25 & 0.005 & 0.0012 & $<0.001$ \\
\hline change & & -0.003 & 0.0045 & 0.56 & -0.006 & 0.0049 & 0.20 & -0.002 & 0.0017 & 0.30 \\
\hline \multicolumn{11}{|l|}{ Winter rye } \\
\hline 1990-1994 & $120 \pm 43$ & 0.005 & 0.0035 & 0.15 & 0.002 & 0.0037 & 0.51 & 0.000 & 0.0016 & 0.98 \\
\hline 1995-2005 & $92 \pm 38$ & 0.004 & 0.0029 & 0.22 & -0.006 & 0.0031 & 0.05 & 0.002 & 0.0013 & 0.07 \\
\hline change & & -0.002 & 0.0045 & 0.74 & -0.009 & 0.0048 & 0.08 & 0.002 & 0.0021 & 0.25 \\
\hline
\end{tabular}

$\mathrm{SD}=$ standard deviation; S.E. $=$ standard error of the mean; $p=$ significance of mean or difference between means

treatment steps of 40 to $65 \mathrm{~kg} \mathrm{ha}^{-1}$ in the field experiments.

In our study, $\mathrm{N}$ had a slightly positive effect on 1000 grain weight of spring barley and spring wheat. However, the observed $12 \mathrm{~kg} \mathrm{ha}^{-1}$ reduction in $\mathrm{N}$ application rate for spring barley, explained only $0.12 \mathrm{~g}(3 \%)$ of the decrease in 1000 grain weight. The decrease in 1000 grain weight for spring barley during the studied periods was 3.9 g. In two Finnish experiments, where increased $\mathrm{N}$ application rate had a positive effect on 1000 grain weight, a zero $\mathrm{N}$ treatment (Seppälä and Kontturi 1987) or $\mathrm{N}$ application rates less than 60 $\mathrm{kg} \mathrm{ha}^{-1}$ (Pietola et al. 1999) most probably caused $\mathrm{N}$ deficiency at grain filling. From these data it seems that a small supplementary $\mathrm{N}$ application can also ensure sufficient $\mathrm{N}$ availability at the time of grain filling.
In our data, P increased 1000 grain weight of spring barley and spring wheat. Again, the magnitude of the P effect was small. The observed 6 $\mathrm{kg} \mathrm{ha}^{-1}$ reduction in $\mathrm{P}$ application rate for spring barley explained only $0.14 \mathrm{~g}(4 \%)$ of the decrease in 1000 grain weight. The decrease in 1000 grain weight of spring barley during the studied periods was $3.9 \mathrm{~g}$. In field experiments, 1000 grain weight of spring barley was 1.0-1.5 g lower without $\mathrm{P}$ fertiliser (Saarela et al. 1995). A similar increase in 1000 grain weight in oats $(1.6 \mathrm{~g})$ was also reported by Peltonen-Sainio et al. (2006) when a $\mathrm{P}$ seed coating was used during a dry and warm growing season. When soil $\mathrm{P}$ availability is low, $\mathrm{P}$ application seems to improve 1000 grain weight by this magnitude. In $\mathrm{P}$ fertiliser treatments, a decrease of $15 \mathrm{~kg} \mathrm{ha}^{-1} \mathrm{P}$ reduced 1000 grain weight only by $0.2-0.3 \mathrm{~g}$ (Saarela et al. 1995). 
Salo, T. et al. Cereal quality changes in Finland in 1990-2005

Table 8. Effect of $1 \mathrm{~kg} P$ fertiliser on grain quality.

\begin{tabular}{|c|c|c|c|c|c|c|c|c|c|c|}
\hline \multirow{2}{*}{$\begin{array}{l}\text { Cereal } \\
\text { Period }\end{array}$} & \multirow{2}{*}{$\begin{array}{l}\text { P rate } \\
\text { mean } \pm \mathrm{SD} \\
\mathrm{kg} \mathrm{ha}^{-1}\end{array}$} & \multicolumn{3}{|c|}{ Test weight } & \multicolumn{3}{|c|}{1000 grain weight } & \multicolumn{3}{|c|}{ Protein concentration } \\
\hline & & $\begin{array}{l}\text { Effect } \\
\mathrm{kg} \mathrm{kg}^{-1}\end{array}$ & $\begin{array}{l}\text { S.E. } \\
\mathrm{kg} \mathrm{kg}^{-1}\end{array}$ & $p$ & $\begin{array}{l}\text { Effect } \\
\mathrm{g} \mathrm{kg}^{-1}\end{array}$ & $\begin{array}{l}\text { S.E. } \\
\text { g kg }^{-1}\end{array}$ & $p$ & $\begin{array}{l}\text { Effect } \\
\% \mathrm{~kg}^{-1}\end{array}$ & $\begin{array}{l}\text { S.E. } \\
\% \mathrm{~kg}^{-1}\end{array}$ & $p$ \\
\hline \multicolumn{11}{|l|}{ Spring barley } \\
\hline 1990-1994 & $24 \pm 14$ & 0.002 & 0.0071 & 0.78 & 0.023 & 0.0081 & $<0.01$ & 0.004 & 0.0023 & 0.05 \\
\hline 1995-2005 & $19 \pm 13$ & -0.006 & 0.0046 & 0.23 & 0.009 & 0.0054 & 0.09 & 0.003 & 0.0015 & 0.02 \\
\hline change & & -0.007 & 0.0084 & 0.37 & -0.014 & 0.0097 & 0.16 & -0.001 & 0.0027 & 0.72 \\
\hline \multicolumn{11}{|l|}{ Oats } \\
\hline 1990-1994 & $24 \pm 16$ & -0.008 & 0.0049 & 0.12 & -0.005 & 0.0042 & 0.24 & 0.000 & 0.0018 & 0.93 \\
\hline 1995-2005 & $19 \pm 13$ & -0.002 & 0.0033 & 0.54 & -0.003 & 0.0027 & 0.32 & 0.004 & 0.0012 & $<0.001$ \\
\hline change & & 0.006 & 0.0059 & 0.34 & 0.002 & 0.0050 & 0.66 & 0.005 & 0.0022 & 0.04 \\
\hline \multicolumn{11}{|l|}{ Spring wheat } \\
\hline 1990-1994 & $23 \pm 11$ & -0.007 & 0.0066 & 0.31 & -0.006 & 0.0050 & 0.27 & 0.002 & 0.0034 & 0.50 \\
\hline 1995-2005 & $17 \pm 11$ & -0.003 & 0.0048 & 0.49 & 0.007 & 0.0031 & 0.03 & -0.001 & 0.0026 & 0.83 \\
\hline change & & 0.003 & 0.0082 & 0.68 & 0.012 & 0.0059 & 0.04 & -0.003 & 0.0043 & 0.50 \\
\hline \multicolumn{11}{|l|}{ Winter wheat } \\
\hline 1990-1994 & $29 \pm 15$ & 0.003 & 0.0075 & 0.69 & 0.000 & 0.0120 & 0.98 & 0.006 & 0.0031 & 0.07 \\
\hline 1995-2005 & $15 \pm 10$ & 0.009 & 0.0087 & 0.32 & 0.024 & 0.0148 & 0.11 & -0.013 & 0.0027 & $<0.001$ \\
\hline change & & 0.006 & 0.0115 & 0.62 & 0.024 & 0.0191 & 0.21 & -0.018 & 0.0041 & $<0.001$ \\
\hline \multicolumn{11}{|l|}{ Winter rye } \\
\hline 1990-1994 & $32 \pm 19$ & 0.006 & 0.0064 & 0.37 & 0.011 & 0.0082 & 0.18 & -0.002 & 0.0027 & 0.43 \\
\hline 1995-2005 & $18 \pm 14$ & 0.007 & 0.0066 & 0.28 & 0.016 & 0.0087 & 0.07 & -0.001 & 0.0028 & 0.71 \\
\hline change & & 0.001 & 0.0093 & 0.88 & 0.005 & 0.0120 & 0.67 & 0.001 & 0.0039 & 0.78 \\
\hline
\end{tabular}

$\mathrm{SD}=$ standard deviation; S.E. $=$ standard error of the mean; $p=$ significance of mean or difference between means

This decrease in 1000 grain weight is similar to the observed $\mathrm{P}$ application rate reduction recorded in our study.

\section{Protein concentration}

In general, protein concentration in the studied cereals first decreased, but then increased again in 2000-2005. Application of $\mathrm{N}$ increased protein concentration of all cereal grains except those of winter rye. Increased $\mathrm{N}$ fertilisation should result in higher protein concentrations as reported in several studies (e.g. Seppälä and Kontturi 1987, Oscarsson et al. 1998, Pietola et al. 1999). However, Esala (1991) assumed that the protein concentration of spring wheat in Finland is mostly dependent on weather conditions. Weather conditions affect $\mathrm{N}$ availability and demand by altering $\mathrm{N}$ leaching, mineralisation and yield formation.

The highest $\mathrm{N}$ application rate effects were $0.007 \% \mathrm{~kg}^{-1}$ for spring wheat, which corresponds with an estimated increase of 0.07 percentage units per $10 \mathrm{~N} \mathrm{~kg} \mathrm{ha}^{-1}$ applied. This is approximately one third of the suggested increase of $0.2-0.3$ percentage units per $10 \mathrm{~N} \mathrm{~kg} \mathrm{ha}^{-1}$ determined for spring wheat protein concentration in a field experiment (Esala 1991). As $\mathrm{N}$ application rates in our study were optimised according to the farmer's views, it is understandable that higher $\mathrm{N}$ application rates do not promote as high a response in protein concentration on-farm as in field experiments.

Protein concentration in spring barley and oats was increased by $\mathrm{P}$ fertilization but it was decreased in winter wheat. This bidirectional 


\section{AGRICULTURAL AND FOOD SCIENCE}

Vol. 16 (2007): 407-420

effect suggests that for spring barley and oats, $\mathrm{P}$ fertiliser improved the plant's ability to take up N. The reasons for this can include improved development rate or photosynthesis at grain filling. For winter wheat, the decrease in protein concentration brought about by increased $\mathrm{P}$ application rates suggests that $\mathrm{P}$ increased yields and diluted protein concentrations (Holford et al. 1992, Saarela et al. 1995).

\section{Conclusions}

The effects of $\mathrm{N}$ and $\mathrm{P}$ on test weight, 1000 grain weight and protein concentration depend on several environmental factors. It is difficult to draw conclusions even from results of controlled field experiments and it is even more challenging to do so from farm surveys. These data show that decreased $\mathrm{N}$ application rates can reduce test weight and 1000 grain weight and protein concentration. In addition, decreased $\mathrm{P}$ application rates have decreased 1000 grain weight and protein concentration on some occasions, although protein concentration can also be increased. The magnitude of reduction through lowered $\mathrm{N}$ and $\mathrm{P}$ application rates is, however, very small and does not alone explain the observed decrease in grain quality.

Acknowledgements: This work was funded by the Finnish Ministry of Agriculture and Forestry.

\section{References}

Bayles, R.A. 1977. Poorly filled grain in the cereal crop. 1. The assessment of poor grain filling. Journal of National Institute of Botany 14: 232-240.

Browne, R. A., White, E. M. \& Burke, J. I. 2003. Effect of nitrogen, seed rate and plant growth regulator (chlormequat chloride) on the grain quality of oats (Avena sativa). Journal of Agricultural Science, Cambridge 141: 249-258.

Browne, R. A., White, E. M. \& Burke, J. I. 2006. Responses of developmental yield formation processes in oats to variety, nitrogen, seed rate and plant growth regulator and their relationship to quality. Journal of Agricultural Science, Cambridge 144: 533-545.
Chalmers, A. G., Dyer, C. J. \& Sylvester-Bradley, R. 1998. Effects of nitrogen fertilizer on the grain yield and quality of winter oats. Journal of Agricultural Science, Cambridge 131: 395-407.

Elliott, D.E., Reuter, D.J., Reddy, G.D. \& Abbott, R.J. 1997. Phosphorus nutrition of spring wheat (Triticum aestivum L.) 1. Effects of phosphorus supply on plant symptoms, yield, components of yield, and plant phosphorus uptake. Australian Journal of Agricultural Research 48: 855-867.

Esala, M. 1991. Split application of nitrogen: effects on the protein in spring wheat and fate of $15 \mathrm{~N}$-labelled nitrogen in the soil-plant system. Annales Agriculturae Fenniae 30: 219-309.

Grant, C.A., Flaten, D.N., Tomasiewicz, D.J. \& Sheppard, S.C. 2001. The importance of early season phosphorus nutrition. Canadian Journal of Plant Science 81: 211-224.

Hay R.K.M. \& Porter, J. 2006. The Physiology of Crop Yield. $2^{\text {nd }}$ ed. Hong Kong. 314 p.

HGCA. 2006. The barley growth guide. Scottish executive. Winter 2005/2006. London. 28 p.

Holford, I.C.R., Doyle, A.D. \& Leckie, C.C. 1992. Nitrogen response characteristics of wheat protein in relation to yield responses and their interactions with phosphorus. Australian Journal of Agricultural Research 43: 969-986.

Hoppo, S.D., Elliott, D.E. \& Reuter, D.J. 1999. Plant tests for diagnosing phosphorus deficiency in barley (Hordeum vulgare L.). Australian Journal of Experimental Agriculture 39: 857-872.

Information Centre of the Ministry of Agriculture and Forestry. 1987-2005. Yearbook of Farm Statistics. Helsinki.

Leitch, M.H. \& Hayes, J. D. 1989. Effects of chlormequat application on stem characteristics, yield and panicle conformation of winter oats. Journal of Agricultural Science, Cambridge 113: $17-26$.

Littell, R.C., Milliken, G.A., Stroup, W.W. \& Wolfinger, R.D. 1996. SAS System for Mixed Models. SAS Institute Inc. Cary, NC. USA. 633 p.

Marshall, H.G., Kolb, F.L. \& Roth, G.W. 1987. Effects of nitrogen fertilizer, seeding rate and row spacing on semi-dwarf and conventional height spring oat. Journal of Crop Science 27: 572-575.

May, W.E., Mohr, R.M., Lafond, G.P., Johnston, A.M. \& Stevenson, F.G. 2004. Effect of nitrogen, seeding rate and cultivar on oat quality and yield in the eastern Canadian prairies. Canadian Journal of Plant Science: 84: 1025-1036.

Ministry of Agriculture and Forestry. 2004. Horisontaalisen maaseudun kehittämisohjelman väliraportti. Manner-Suomi. Summary: Mid-term evaluation of the horizontal rural development programme. MMM:n julkaisuja 1/2004. 272 p.

Mohr, R.M., Grant, C.A., May, W.M. \& Stevenson, F.G. 2007. The influence of nitrogen, phosphorus and potash fertilizer application on oat yield and quality. Canadian Journal of Plant Science: 87: 459-468.

Öfversten, J., Jauhiainen, L. \& Kangas, A. 2004. Contribution of new varieties to cereal yields in Finland between 1973 and 2003. Journal of Agricultural Science, Cambridge 142: 281-287.

Ohm, H. W. 1976. Response of 21 oat cultivars to nitrogen fertilization. Agronomy Journal 68: 773-775.

Oscarsson, M., Andersson, R., Åman, P., Olofsson, S. \& Jonsson, A. 1998. Effects of cultivar, nitrogen fertilization rate and environment on yield and grain quality of barley. Journal of the Science of Food and Agriculture 78: 359-366.

Peltonen-Sainio, P. \& Peltonen, J. 1995. Floral set and abortion in oat and wheat under high and low nitrogen regimes. European Journal of Agronomy 4: 253-262.

Peltonen-Sainio, P., Kontturi, M. \& Peltonen, J. 2006. Phosphorus seed coating enhancement on early growth and yield components in oat. Agronomy Journal 98: 206-211. 
Salo, T. et al. Cereal quality changes in Finland in 1990-2005

Peltonen-Sainio, P., Kangas, A., Salo, Y. \& Jauhiainen, L. 2007. Grain number dominates grain weight in temperate cereal yield determination: Evidence based on 30 years multilocation trials. Field Crops Research: 179-188.

Pietola, L., Tanni, R. \& Elonen, P. 1999. Responses of yield and $\mathrm{N}$ use of spring sown crops to $\mathrm{N}$ fertilization, with special reference to the use of plant growth regulators. Agricultural and Food Science in Finland 8: 423-440.

Rajala, A., Peltonen-Sainio, P., Kauppila, R., Wilhemson, A., Reinikainen, P. \& Kleemola, J. 2007. Within-field variation in grain yield, yield components and quality traits of two-row barley. Journal of Agricultural Science, Cambridge 145: 445-454.

Saarela, I., Järvi, A., Hakkola, H. \& Rinne, K. 1995. Fosforilannoituksen porraskokeet 1977 - 1994. Vuosittain annetun fosforimäärän vaikutus maan viljavuuteen ja peltokasvien satoon monivuotisissa kenttäkokeissa. Maatalouden tutkimuskeskus, Tiedote 16/95. $94 \mathrm{~s}$.

Salo, T., Lemola, R. \& Esala, M. 2007. National and regional net $\mathrm{N}$ balances in Finland in 1990-2005. Agricultural and Food Science 16: 366-375.

Salopelto, J. 2004. ISO-VILJA ${ }^{\circledR}$. Viljatutkimus 2004. Suomen Rehu Oy. 26 p. Cited 21 January 2007. Available on the internet: http://www.farmit.net/farmit/fi/03_kasvinviljely/10_viljanlaatu/01_ISO-VILJA-teknologia/03_viljatutkimuksen_raportit/ Viljatutkimus_2004.pdf

Salopelto, J. 2005. ISO-VILJA ${ }^{\circledR}$. Viljatutkimus 2005. Suomen Rehu Oy. 36 p. Cited 21 January 2007. Available on the internet: http://www.farmit.net/farmit/fi/03_kasvinviljely/10_viljanlaatu/01_ISO-VILJA-teknologia/03_viljatutkimuksen_raportit/ Viljatutkimus_2005.pdf
Seppälä, R. \& Kontturi, M. 1987. Mallasohran reagointi typpilannoitukseen. Maatalouden tutkimuskeskus, Tiedote 8/87: 1-66.

Slafer, G.A. \& Peltonen-Sainio, P. 2001. Yield trends of temperate cereals in high latitude countries from 1940 to 1998. Agricultural and Food Science in Finland 10: $121-131$.

Taylor, B.R. \& Blackett, G. A. 1982. Influence of some husbandry practices on the physical properties of spring barley grain. Journal of the Science of Food and Agriculture 33: 133-139

Turtola, E. \& Kemppainen, E. 1998. Nitrogen and phosphorus losses in surface runoff and drainage water after application of slurry and mineral fertilizer to perennial grass ley. Agricultural and Food Science in Finland 7: 569-581.

Uusitalo, R., Turtola, E., Grönroos, J., Kivistö, J., Mäntylahti, V., Turtola, A., Lemola, R. \& Salo, T. 2007. Finnish trends in phosphorus balances and soil test phosphorus. Agricultural and Food Science 16: 301-316.

Viljavuuspalvelu 1990. Viljavuustutkimuksen tulkinta peltoviljelyssä. Viljavuuspalvelu Oy. 70 p.

Viljavuuspalvelu 1995. Viljavuustutkimuksen tulkinta peltoviljelyssä. Viljavuuspalvelu Oy. $30 \mathrm{p}$.

Viljavuuspalvelu 2000. Viljavuustutkimuksen tulkinta peltoviljelyssä. Viljavuuspalvelu Oy. 32 p.

\title{
SELOSTUS
}

\section{Typpi- ja fosforilannoituksen vaikutus viljasadon laadun kehitykseen 1990-2005}

\author{
Tapio Salo, Juha Eskelinen, Lauri Jauhiainen ja Mirja Kartio \\ MTT Maa- ja elintarviketalouden tutkimuskeskus ja Evira
}

\begin{abstract}
Ympäristötuen ehtojen mukaisen peruslannoituksen ja tarkennetun lannoituksen on pelätty alentavan viljasadon laatua. Tässä tutkimuksessa verrattiin Elintarviketurvallisuusviraston Viljantarkastuksen analysoimien viljanäytteiden laatua ja taustatietoja vuosilta 1990-2005. Tilastolliseen analyysiin valittiin laatutekijöistä hehtolitran ja tuhannen siemenen paino sekä valkuaispitoisuus. Taustatiedoista otettiin huomioon typpi- ja fosforilannoitustasojen lisäksi lajike, maaseutukeskus, maalaji ja vuosi. Ensin tutkittiin lannoitustasojen ja laatutekijöiden muutosta kolmen eri ajanjakson, vuosien 1990-1994, 1995-1999 ja 2000-2005 välillä. Sen jälkeen analysoitiin typpi- ja fosforilannoitustasojen vaikutus laatutekijöihin. Typpi- ja fosforilannoituksen väheneminen näkyy selvästi myös tässä aineistossa. Lisäksi hehtolitran ja tuhannen siemenen paino ovat laskeneet selkeästi tarkasteluaikana. Typ-
\end{abstract}

pilannoituksen väheneminen kytkeytyi hehtolitran ja tuhannen siemenen painon sekä valkuaispitoisuuden pienenemiseen. Myös fosforilannoituksen väheneminen liittyi tuhannen siemenen painon pienenemiseen. Vaikutuksille arvioidut kertoimet olivat kuitenkin alhaisia ja selittivät havaituista hehtolitran ja tuhannen siemenen painon vähenemisistä alle kymmenen prosenttia. Typpi- ja fosforilannoituksen vaikutus hehtolitran ja tuhannen siemenen painoon sekä valkuaispitoisuuteen riippuu lajin ja lajikkeen ominaisuuksien lisäksi vahvasti kasvukauden säästä. Kontrolloiduissa kenttäkokeissakin saadaan usein hyvin vaihtelevia tuloksia typpi- ja fosforilannoituksen vaikutuksesta laatuun. Tulevaisuudessa suuria analyysisarjoja tutkittaessa olisi lannoituksen lisäksi pyrittävä hankkimaan mahdollisimman hyvät taustatiedot myös kasvinsuojelusta ja muokkausmenetelmistä. 